\title{
Leadership model and planning strategies in private Catholic colleges during the COVID-19 pandemic
}

\author{
Lorensius $^{1 *}$ \\ Warman $^{2}$ \\ Silpanus ${ }^{3}$ \\ Theresia Ping ${ }^{4}$ \\ 1-2Education Management, Universitas Mulawarman, Samarinda, Indonesia \\ ${ }^{3-4}$ Catholic Religion Education, STKPK Bina Insan, Samarinda, Indonesia
}

\begin{abstract}
This paper aims to examine the leadership model and planning strategy of private Catholic colleges during the COVID-19 pandemic in Samarinda City, East Kalimantan, Indonesia. This study adopted a qualitative approach using interviews, observations, and documentation to collect data from 10 lecturers and 7 staff as a source of information. The collected data were then analyzed descriptively. The results of this study indicate that the leadership model that often appears as a hallmark of private Catholic college leadership during the COVID-19 pandemic is a situational and distributed leadership model, with an emphasis on principles of leadership servant in dealing with changing organizational needs. The planning strategy carried out shows a visionary leadership model, college leaders can rearrange strategies that are adapted to the situation in developing educational programs and improving the quality of the college.
\end{abstract}

\section{KEYWORDS}

leadership model; planning strategy; COVID-19 pandemic; private Catholic college, Indonesia

Received: 18 June 2021 Accepted: 22 June 2021 Published: 24 June 2021

\section{Introduction}

This paper aims to examine the leadership model and planning strategy of private Catholic colleges during the Covid-19 pandemic in Samarinda City, East Kalimantan Province, Indonesia. Private catholic college referred to here are college under the auspices of the Directorate General of Catholic Community Guidance at the Ministry of Religion of the Republic of Indonesia, which provide service to the nation and the church as well as a reliable pastoral agent for the Catholic Church in Indonesia (Kirchberger, 2014). At this time which is marked by very rapid social, political, and economic changes, especially pressure due to the Covid-19 pandemic, the role of universities in society is very important. In this context, private Catholic college produce graduates of Catholic religious educators and teachers (religious teachers in schools), catechists (faith teachers in

\footnotetext{
CONTACT Lorensius (M) lorensiusamon@qmail.id
}

C 2021 The Author(s). Published with license by Lighthouse Publishing.

This is an Open Access article distributed under the terms of the Creative Commons Attribution-ShareAlike 4.0 International (CC BY-SA 4.0) License (https://creativecommons.org/licenses/by-sa/4.0/), which allows others to share the work with an acknowledgement of the work's authorship and initial publication in this journal. 
parishes), researchers, and entrepreneurs (Sarumaha, 2018), are required to be able to develop strategic planning for their institutions.

In the first place, the role of the leadership of private Catholic college is very central, namely building high ideals to bring the institution into a modern and competitive Catholic college institution. Produce scholars who have expertise in the field of religion, who in the end become Catholic religious education teachers, parish catechists, extension workers, researchers, or entrepreneurs (Sarumaha, 2018). The Catholic Church currently needs a cadre of leaders, especially regarding the availability of catechists and religious teachers, so it is quite worrying, especially in public schools, there are still many Catholic children who do not receive religious lessons from Catholic religion teachers (John, 2018). Given the nature of this, the leadership model and planning strategy are important things to achieve the goal of restoring and transforming organizational behavior that has been considered unsportsmanlike (Sarumaha, 2018). The Catholic college is a symbol for the Catholic Church in empowering Catholics and the representation of Catholic community development so that they can participate in national development.

Among the studies on leadership models, Hermans (2021) reported the results of a research study of 198 Don Bosco catholic school leaders in India. The study measures three leadership scales, namely transformational leadership, transactional leadership, and passive leadership. Hermans (2021) explains that catholic schools need to build a model of leadership with discernment that can be characterized as individual and communal, future-oriented, dealing with decision-making in general, focusing on purity of heart and emphasizing theological ethics as a source of belief. The role of leadership is seen as a key factor to improve school effectiveness and performance (Ningsih et al., 2020; Day et al., 2016). The role of the leader in this position is unique because it is located between the public and internal areas (Tolo et al., 2020), so that in carrying out its leadership function it requires the support, trust, and active involvement of all components (Bryk, 2010; Heck \& Hallinger, 2009; Sebastian et al., 2019), as well as creativity in innovating and advancing schools and improving learning outcomes (Pietsch et al., 2019; Zhang et al., 2018).

Leonangung et al., (2019) investigated the leadership of Catholic universities in Flores. This study involved 44 lecturers as participants from Catholic colleges in Flores. The results of this study indicate that the leadership practice applied by the school principal is a collegial leadership model. This can be seen from the leadership strategy of the school principal who gives confidence to lecturers (especially young lecturers) to become leaders in lecturer meetings and tridharma activities. This is done by the head of the school with the aim of increasing the capacity of lecturers and contributing to improving the quality of higher education institutions. The issue of leadership models in Catholic educational institutions is very interesting. According to Francis (2014), Catholic leaders must be committed to acquiring distinctive leadership qualities and acting for the common good.

In another qualitative study, Leonangung Edu et al., (2019) explained that the leadership practice applied by the principal is a collegial leadership model. This can be seen from the leadership strategy of the school principal who gives confidence to lecturers (especially young lecturers) to become leaders in lecturer meetings and tridharma activities. This is done by the head of the school with the aim of increasing the capacity of lecturers and contributing to improving the quality of higher education institutions. The issue of leadership models in Catholic educational institutions is very interesting. According to Francis (2014), Catholic leaders must be committed to acquiring distinctive leadership qualities and acting for the common good.

Despite this, a large amount of research on leadership during the pandemic refers to the ideal leadership model. Ribbins (2007) states that there are still few detailed leadership studies and contextual reports on what leaders do and why they do it under what circumstances, how and why 
others. respond to what they did, and what the results were (Ribbins, 2007:359). Based on this, this paper mainly examines the leadership model and planning strategy for private Catholic college in tackling the Covid-19 pandemic. The limited literature on Catholic college leadership is clear. Thus, this study intends to fill the literature gap by using evidence from a private catholic college in Samarinda, East Kalimantan.

\section{Literature review}

\section{Educational leadership in general}

The leadership literature is oriented towards models and instruments, describing different leadership styles that are considered important, such as various leadership paradigms (Avolio, 2011), and service leadership (Ehrhart, 2004). The most commonly used models focus on one or two aspects of leadership, and ignore others. Furthermore, most models focus on the positive side of leadership. In particular, previous studies have tended to study leadership styles associated with positive leadership outcomes, although the negative aspects of leadership are more intensively studied today (e.g., ethical and despotic leadership, the relationship with leader social responsibility, top management team effectiveness and subordinate optimism (De Hoogh \& Den Hartog, 2008; Hogan \& Hogan, 2001).

The definition of educational leadership has evolved to encompass a wider spectrum of knowledge, characteristics, dispositions, and skills oriented towards competitive perspectives and understandings with little agreement on what should or should be included in the discipline of educational leadership (Bush, 2007). Beaudoin (2003:520) for example, argues that 'leadership speaks to a ubiquitous, identifiable set of human activities that support and assist, particularly in relation to change', meaning that leadership talks about a series of identifiable human activities that support and help especially for a change. The role of educational leadership is currently undergoing major changes, becoming increasingly complex (Kelkay, 2018), especially during this time of the pandemic Coronavirus Disease (Covid-19), many school leaders are experiencing stress due to the pandemic situation, they only rely on guidance on responses, processes, and practices. Covid-19 procedures, and protocols (Harris \& Jones, 2020).

Leadership is a process by which a person influences a group of people to achieve a common goal (Northouse, 2015). The role of the leader is not static but dynamic, changing over time. A recent study by Dagnew Kelkay (2020) reports that the role of a college leader has undergone major changes, has become more complex, and shifted from a manager-building role to a visionary situational leader. In terms of improving learning effectiveness, a study by Lochmiller and Mancinelli (2019) contributes to a global body of research examining the enactment of educational leaders' discourses and policy steps towards increasing leader autonomy. Like many countries in the world, the Australian school system is competing to improve learning achievement through national and international examinations (Drummer et al., 2018).

The conceptualization of educational leadership in this study refers to an educational leadership model that establishes the qualities, knowledge, and skills needed to lead educational institutions during the Covid-19 pandemic. Educational leadership aims to improve learning outcomes, create conditions for effective teaching and learning, develop learning organizations, build networks, and develop subordinates to become leaders (Hallinger \& Murphy, 1985). Building trusting relationships and focusing on internal and external learning is at the core of the educational leadership role (Sebastian et al., 2019). Reliance on the collective or collaborative ability of organizational members and teams to lead change in a volatile or dynamic environment. However, leader-focused theory and authority structures make it difficult to fully benefit from the collective capabilities of groups or organizational members organisasi (Sebastian et al., 2019; Abonyi \& Sofo, 
2019). The underlying premise of leadership in complex organizations is that 'answers can be found in the community' in group-centered organizations where 'everyone can learn constantly' (Popper \& Lipshitz, 1998).

According to Hallinger et al., (2020) from 1980 to 2014, the most studied leadership models were the distributed, instructional, and transformational leadership models. Purwanto et al., (2019) analyzed the influence of higher education leadership styles, involving 120 lecturers from 14 private universities in Tangerang. The results of this study conclude that transformational, transactional and authoritarian leadership styles have a positive and significant effect on performance. Educational leaders must navigate accountability and autonomy, equality and excellence, welfare and workload especially during the current Covid-19 pandemic (Netolicky, 2020). The Gardner McTaggart (2020) study investigates educational leadership in global crisis situations. This paper disseminates critical theory to examine educational leadership in the 21 st Century. It is found that the global crisis facing today is caused by the dominance of system interests that harm the survival of many people. According to Gardner-McTaggart (2020), educational leadership today has the potential and influence to facilitate global thinking and intersubjectivities to address problems.

\section{Catholic-oriented educational leadership}

The orientation of educational leadership in Catholicism refers to church documents published since the Second Vatican Council to consider aspects of leadership in Catholic education. These aspects include the call for leadership, commitment to the Catholic educational mission, the spiritual dimension, and the testimony of the gospel. The role of Catholic school leaders is very important because they carry out the special mission of the church, and to them the church entrusts the work of Catholic education, to shape human personality, in cultural communication and pedagogy in ecclesiastical, spiritual, and pastoral dimensions (Congregation for Catholic education, 1984). In this case, the Catholic church emphasizes the relationship between the Catholic leadership who is obedient and loyal to the Catholic identity. This vocation demands a special quality of mind and heart, a continuous readiness to renew and adapt in all situations(Pope Paul VI, 1965).

Catholic school leaders are prepared and formed in the faith to build a Catholic culture in Catholic schools with the aim of becoming a good school. superior. Faith formation in the form of prayer, sacraments, scriptures, doctrines, and knowledge of the nature and purpose of Catholic education is an important component for forming leaders and teachers in Catholic schools (United States Conference of Catholic Bishops, 2015). In the difficult situation due to the current Covid-19 pandemic, Catholic school leaders are bound by the obligation to ensure that all school personnel, especially in private Catholic colleges receive adequate preparation to serve effectively. Moreover, they must serve according to the faith they profess and be able to interpret the demands of society in the real situation of its manifestation today. This also increases cooperation between Catholic high schools and parents in education, while respecting their responsibilities as first and natural educators (KWI, 2020).

Catholic school leaders are more than just organizational managers. They are real educational leaders when they were the first to take on this responsibility, which is also an ecclesiastical and pastoral mission rooted in the relationship with the pastors of the church. Catholic school leaders have a unique obligation to provide the necessary support to promote a culture of dialogue, encounter and mutual recognition, both inside and outside the school, enhancing the collaboration that is possible for intercultural harmony. This illustrates that Catholic school leaders must be able to blaze new trails, seek to address the needs of the current generation, with concern for everyone, and without harming future generations (Anggal et al., 2019). Catholic leaders are required not only 
to be proficient in operational, curriculum, and management fields, but also to be able to strengthen the identity of a Catholic school by building a Catholic culture and community, carrying out faith building, which is integrated with church doctrine. Leaders of private Catholic high schools today expand the great responsibility of the church in the ministry of Catholic education. Their vocation is a special vocation, namely the apostolic vocation of Catholic education, where they are required to live life and bear witness to the Gospel. That is, pen leadership not only educates 'humanize humans' but also becomes an example and strengthens the faith of everyone they meet and follow them.

\section{Methods}

The study adopteda qualitative approach with a descriptive method (Gay \& Airasian, 1992). The process used in this study consists of three distinct stages. The first stage consisted of a literature review (Grant \& Booth, 2009; Wee \& Banister, 2016) on how to model college leadership and strategy during the pandemic. The second stage presents research data to see the planning and leadership strategies implemented by higher education leaders between March 2020 to May 2021. The third stage consists of analyzing focus group data using a combination of Creswell (2008), the process of data analysis using an interactive model to provide an overview of the overall research interpretation (Miles dan Huberman, 1994).

The authors try to find social symptoms and events that emerged, especially during the Covid19 pandemic in a private Catholic college in Samarinda, East Kalimantan, Indonesia by involving school leaders and education staff consisting of 10 (ten) lecturers and 7 (seven) employees as a source of information. Data collection techniques used were interviews, observation, and documentation (Miles and Huberman, 1994).

\section{Results and discussion}

\section{Leading and managing college during the pandemic}

At the beginning of 2020, Indonesia was shocked by the emergence of the Covid-19 pandemic outbreak and it had an impact on all aspects of daily life, destroying economic growth and disrupting the education sector globally. In just a few months Covid-19 has become a 'supernova' (Azorín, 2020), creating undeniable chaos and shaking up the fabric of education. The pandemic has highlighted education leaders to define learning models as academic activities and get support for online learning. According to UNESCO, 1.6 billion young people have dropped out of school during this crisis, as Zhao (2020) pointed out that almost all schools have been stopped and teaching has been significantly regulated, including universities in Indonesia.

For leader of private catholic colleges, working in these demanding and chaotic conditions, the pressure is relentless, the options are limited. Staff meetings, meetings with students, and corridor chats with coworkers, which are campus activities, have disappeared. All informal moments are halted, parents of students and faculty are now in an educational situation full of concern for their children, awaiting the return of normal services or hoping for some new normal that might offer stability, continuity, and certainty. The obvious reality is that neither is likely to happen any time soon. This is the perfect storm for educational institutions with imperfect leadership responses. Field notes from this study suggest that in times of crisis, leaders must act quickly and with foresight but also with a balance of anxiety and doubt over the choices, consequences, and side effects of the actions taken.

Current college leaders both rely on health protocol guidelines to prevent the spread of Covid19 in their college environment. Lecturers and education staff are required to face extra pressures 
such as staffing problems and increased workloads. Higher education leaders also have to take on other important tasks, which are quite time-consuming, such as in the case of a private Catholic college in Samarinda, assisting in contact tracing and providing personal protective equipment for medical personnel, distributing hand sanitizers and masks for lecturers, employees, students, and the general public (Lorensius, 2020). The main professionalism during the Covid-19 pandemic is described by Stone-Johnson and Miles Weiner (2020), that the role of university leaders as frontline workers is very important because they deal with social problems, maintain student morale, and communicate with parents in making policies. related to academic and non-academic activities on campus. In addition, although the work aspect of work is increasing, an indication of the central role of leadership during the Covid-19 pandemic is to improve the quality of universities and ensure the continuity of the student's academic learning process, such as the response vice chairman of the academic field when discussing education issues during campus closures during the pandemic.

“...I often remind students to stay focused on learning, even though at this time learning cannot be done face-to-face, we must switch to online learning to overcome student lecture problems, and must be prepared properly because it is important for us to maintain the quality of learning students." (Vice-Chairman)

In addition, not only college leaders and lecturers are required to have technical skills to meet the demands of online learning, but they are also required to pay attention to academic needs and build partnerships with students' parents and the community to ensure an inclusive and effective approach to solving learning problems. This illustrates what Dagnew Kelkay (2020) means that the role of leaders in managing higher education is currently increasingly complex, leading to a visionary situational leadership model. Even in a difficult situation due to the pandemic, all elements of education managers must be optimistic about completing their tasks, this is in line with Hallinger et al., (2020) in a systematic review of leadership models, that the most studied leadership model is distributed leadership. Furthermore, the Deputy Head of Academic Affairs stated:

"Our lecturers ask us to adjust the learning process at this time, because it is not possible to conduct face-to-face lectures, we have also asked students, especially those who live in dormitories, to return to their parents' houses because we will close the dormitory. can also monitor student learning with the help of parents from home." (Vice-Chairman)

The head of college also emphasized the importance of being flexible and adaptable when managing external expectations and pressures. For example, with little warning, school principals began receiving a wealth of information through circulars and information shared on social media that required immediate planning decisions to be made at the internal campus level. This situation is also described by Netolicky (2020) that today's educational leaders must be able to navigate the direction of leadership that is appropriate to the situation, especially during the current pandemic.

“...it's really worrying, the information circulating in the community from social media is very fast, and it also has an impact on the campus, because there are parents of students, is the campus still open or closed? So according to the letter from the government, we follow that and our decision to send back students who live in dormitories and make adjustments to academic activities to prevent the spread of covid in this campus environment." (Chairman)

The results of interviews with college leaders illustrate that distributed leadership has become one way to maintain the academic learning process at the private Catholic college in Samarinda City. Distributed and situational leadership has become the response of higher education leadership in 
overcoming the current crisis, and this leadership model is a necessity to survive in difficult situations due to the Covid-19 pandemic outbreak. The results are reinforced by the statement of Harris dan Jones (2020) that distributed leadership is the default in responding to the current crisis. However, the concept and need for implementing distributed leadership are not new, and there are many versions (Spillane, 2004). Nonetheless, one consistent aspect of distributed leadership that remains constant in the literature is that distributed leadership practices are shaped in organizational interactions and situations (Spillane, 2004).

\section{College planning leadership and strategy during the Covid-19 pandemic}

Leadership practices and college planning strategies have changed a lot, in large part due to the Covid-19 pandemic. This study underscores that the principles of good leadership in this situation are constant and context-responsive, namely having a clear vision and being responsive to changing situations in educational leadership practices due to Covid-19. Crisis management is an important skill of a college leader, especially to assist the implementation of tasks and solve problems in the management of the college-led (De Hoogh dan Den Hartog, 2008; Hogan dan Hogan, 2001). The empirical data of this study shows that the delegation and division of tasks and leadership responsibilities can no longer be carried out because the workload and work stress levels of staff are increasing. As stated by the head of private Catholic Religious Colleges below.

"Currently we are trying to protect lecturers, employees and students from being exposed to Covid, that's why the division of tasks for academic activities and Easter service or community service has been abolished from March 18 to April 20. In fact, lecturers and staff are always eager to work together. accept assignments, especially those who are still young, but now everything is limited and we also understand this situation, so it's no wonder why some of the tasks we are given can't be carried out, it's not as usual always ready." (Chairman)

In this regard, college leadership appears to be faced with increasing planning and leadership responsibilities under pressure and being distributed among other staff members. During this data analysis, it appears that the most dominant theme that emerged from the data group was a strong ethics of caring for all campus academics, as stated by the following leaders:

"I feel that it is time for us to take care of ourselves more, by adhering to existing health protocols, so we don't give too heavy a task to lecturers or staff on campus assignments, so that they don't get more stressed with the current situation coupled with piled up tasks." (Vice Chair)

"We temporarily stop campus academic activities so that lecturers and staff can take more time to rest and take care of their health with their families at home, we also limit their duties such as thesis supervisors, which can be done online, without having to come to campus again, as well as online lectures, if possible, can be carried out from home, we do not give too heavy a task, because we are all currently under pressure from the Covid-19 situation." (Chairman)

The current situation has presented the education system with unexpected challenges, at the decision-making level, interviewed college leaders are sometimes unhappy with circulars from the government regarding planning strategies during the pandemic. The following statement illustrates this.

"The situation is different, the government's policy requires us to conduct online lectures, while most of our students are from remote areas where internet signals are difficult to reach, we have tracked almost $50 \%$ of our students living in areas with poor signal, and they have to look for a signal to the capital city. sub-districts that are far from their villages, it is not possible to conduct online lectures in the near future, for strategic leadership there is not yet, 
because we are still thinking of solutions for that, so that students who have returned home can still go to college." (Chairman)

“...I think there needs to be strategic leadership from above in order to overcome the learning problems in this situation." (Staff)

"The facts on the ground are different, we are in Samarinda and in Java, we have to be able to adjust the situation, be more flexible for good decisions, we need that leadership strategy, we as lecturers are very worried, we don't know what to do." (Lecturer)

The situation above shows that college leaders are currently still confused to solve the problems that occur, even though there is a planning strategy from the government but it is not properly applied to the college they lead everything needs adjustment, for now, the leadership can do nothing but surrender to the situation because the most important thing for them at this time is to ensure the safety of everyone's health and not be stressed in facing a tense situation. As the Catholic college private differs from public college, in this situation the leaders of private college are left alone to navigate this new terrain (Gardner-McTaggart, 2020), some of the information and solutions they receive are deemed inadequate to enable strategic leadership and planning to take place, appropriate and distributed, it appears to be a source of frustration for them.

The situation above shows that college leaders are currently still confused to solve the problems that occur, even though there is a planning strategy from the government but it is not properly applied to the college they lead. Everything needs adjustment, for now, the leadership can do nothing but surrender to the situation because the most important thing for them at this time is to ensure the safety of everyone's health and not be stressed in facing a tense situation. As the catholic private college differs from public universities, in this situation the leaders of private universities are left alone to navigate this new field. Some of the information and solutions they receive are deemed inadequate to allow for proper and distributed leadership and planning strategies, instead, it appears to be a source of frustration for them.

Different from other colleges, private Catholic colleges have completed dormitory facilities for students, but this is not enough to be a solution in the Covid-19 emergency situation, it is even considered to have the potential to spread the virus. However, after a long time finally found a solution by daring to take risks with the decision made, namely asking students to return to the dormitory by adhering to strict health protocols. The purpose of this policy is that students can continue their lectures that have been stopped, even though they continue through online lectures facilitated by the campus. This was conveyed by the leadership, lecturers, and staff during further interviews.

"Currently we have issued a decision to accept students back into the dormitory, this decision is indeed difficult but it must be done so that students and lecturers can complete the lectures that were delayed because it is impossible to wait until the situation is safe, ... will soon enter the new academic year, then we agree to this policy with all the risks." (Chairman)

"...yes, students have to go to dormitories so they can study online, parents and they are also willing to follow strict health protocols, we have provided all the necessary health facilities, ... we are ready with a careful planning strategy, lecturers- lecturers will continue to work from home, students study from dormitories, and employees can enter the office, we adjust everything according to government policies, ... students must show the results of the covid test to ensure they can enter the dormitory and campus environment." (Vice-Chair)

"...it was a decision in a joint meeting. This strategic plan will continue until next semester, we employees will help to handle all student equipment in the dormitory and provide online administration, because they are not allowed to leave the environment. dormitories, ... 
dormitories and campuses are currently integrated, ... all facilities to support this policy have been prepared in advance with the leaders and lecturers." (Staff)

Based on the description above, leaders, lecturers, and educational staff show the characteristics of an attitude of concern, open communication from various directions, decision making is carried out jointly or by consensus, direct supervision and monitoring of the process, and motivates by meeting the needs needed in overcoming problems faced. The precautionary principle forms the basis for the decisions made, with conclusions about overcoming, managing, and surviving in difficult situations due to the Covid-19 pandemic. Of course, the language used by the informants is very similar and accurately describes the emergency they face. Coming to a fairly normal situation, after going through a difficult period of approximately two semesters of study, finally, the head of the chairman college was able to continue and develop institutional programs, such as assistance in preparing for institutional accreditation, further studies of lecturers and employees, and developing collaboration with government agencies.

Development of student education programs both academic and extracurricular in accordance with the pandemic situation, such as technical guidance activities for learning media, faith, and character development activities for dormitory students through monthly recollections, daily mass and worship, student entrepreneurship, talent development, and interest in music and church liturgical singing, as well as monthly communal recreation. The program of activities is carried out online and offline, adjusting to the situation and conditions.

This section explores the planning strategies used by leaders of private Catholic universities in Samarinda during the Covid-19 pandemic. The results obtained from this study show that unsurprisingly, in many cases, evaluation and planning activities that were agreed upon prior to the pandemic have become less of a priority for university leaders. On the other hand, these difficult times saw the emergence of newer plans to implement online learning, and beyond that, the health and welfare of students, faculty, and staff of higher education institutions emerged. Furthermore, as described in the interviews, the chairman of the college, lecturers, and staff spoke about the need to limit distributed leadership and planning in their college. This is a significant break from the period before the Covid-19 pandemic.

The current situation of the Covid-19 pandemic indicates the importance of networking in education, especially to address the learning problems of lecturers and students. A positive aspect of the current pandemic is the emergence of collaborative networks during uncertain times (O'Hara et al., 2021), and collaborative and distributed leadership is a new imperative in educational leadership. This distributed leadership practice is in line with the opinion of Beauchamp et al., (2021) that the distributed form of leadership becomes a real strength and allows the delegation of responsibilities and some continuity of decision making in a network in an educational environment.

Educational leadership is currently centered on social interaction in the educational environment. Literature review on the interaction of administrative and work in organizational systems: (1) rational systems theory and scientific management principles related to efficiency and effectiveness (e.g. Fayol dan Storrs, 1949; Taylor, 1947), (2) the theory of human relations with nature (McGregor and Cutcher-Gershenfeld, 1960), and (3) open systems theory (Callahan, 1962). The recent leadership literature is largely empirical with much of the research grounded in organizational theory. In international leadership studies, many researchers investigate how educational leaders contribute to institutional success and the impact of leadership models is seen as an influence variable and a control variable (Leithwood \& Wahlstrom, 2008). Leadership at Catholic universities, Sandiasa (2017) suggests using the characteristics of leadership, both when leading and when choosing prospective leaders. The same concept has been expressed long before by Pope Francis, that there is only one path to leadership and that is (Francis, 2014). 


\section{Conclusion}

The conclusion from the results of this study shows that, the leadership model that often appears as a leadership characteristic of private Catholic universities during the Covid-19 pandemic is a situational and distributed leadership model, namely leaders are able to switch from traditional leadership models to other leadership models, with an emphasis on the principle of Catholic educational leadership that serves to meet the changing needs of the organization. The planning strategy carried out shows a visionary leadership model, because even in a stressful situation, higher education leaders are able to rearrange strategies that are adapted to the situation to develop educational programs and improve the quality of higher education. Of the various leadership models that have been discussed, situational leadership and servant leadership are the most suitable for the current private Catholic college leadership model. The results of this study can be used as a future researchers' reference for their research success.

However, this research is not without limitations. Although this research can provide an overview of leadership models and planning strategies during the Covid-19 pandemic in private Catholic universities, this research was conducted among a limited number of participants and only in certain universities. Therefore, it is necessary toconduct new research with a larger number of participants and include the representation of private Catholic universities in Indonesia, as well as develop other leadership model variables, such as transformational, instructional or other leadership models, so as to be able to describe relevant leadership models. and contextual with a more in-depth study quality.

\section{Acknowledgements}

We would like to express our gratitude to all parties taking part in this study. Our gratitude also goes to the anonymous reviewers for providing us with constructive comments on the earlier version of this paper.

\section{Funding}

This research did not receive a specific grant from any funding agency in the public, commercial, or non-profit sector.

\section{References}

Abonyi, U. K., \& Sofo, F. (2019). Exploring instructional leadership practices of leaders in Ghanaian basic schools. International Journal of Leadership in Education, 1-17. https://doi.org/10.1080/13603124.2019.1629628

Anggal, N., Kristianus, K., \& Lio, Z. D. (2019). Kepemimpinan visioner kepala sekolah dalam meningkatkan kinerja guru. Gaudium Vestrum: Jurnal Kateketik Pastoral, 3(1), 14-25. https://ojs.stkpkbi.ac.id/index.php/jgv/article/view/87

Avolio, B. J. (2011). Full range leadership development. In Full Range Leadership Development. Sage Publications. https://doi.org/10.4135/9781483349107

Azorín, C. (2020). Beyond COVID-19 supernova. Is another education coming? Journal of Professional Capital and Community, 5(3-4), 381-390. https://doi.org/10.1108/JPCC-05-2020-0019

Beauchamp, G., Hulme, M., Clarke, L., Hamilton, L., \& Harvey, J. A. (2021). 'People miss people': A study of school leadership and management in the four nations of the United Kingdom in the early stage of the COVID-19 pandemic. Educational Management Administration \& Leadership, 49(3), 375-392.

Beaudoin, M. F. (2003). Distance education leadership: An essential role for the new century. Journal of Leadership Studies, 8(3), 131-144. https://doi.org/10.1177/107179190200800311

Bryk, A. S. (2010). Organizing schools for improvement. Phi Delta Kappan, 91(7), 23-30. https://doi.org/10.1177/003172171009100705

Bush, T. (2007). Educational leadership and management: Theory, policy, and practice. Main Issues Of Pedagogy 
And Psychology, 3(3), 31-43. https://doi.org/10.24234/miopap.v3i3.255

Callahan, R. E. (1962). Education and the cult of efficiency. University of Chicago Press.

Congregation for Catholic education. (1984). Lay Catholics in Schools: Witnesses to Faith. Vatican.Va, 630-661. http://www.vatican.va/roman_curia/congregations/ccatheduc/documents/rc_con_ccatheduc_doc_19821 015_lay-catholics_en.html

Creswell, J. W. (2008). Research design: Qualitative, quantitative, and mixed methods approaches. Sage publications.

Dagnew Kelkay, A. (2020). School principals' and supervisors' leadership practices in teachers' continuous professional development program: in secondary school of Bahir Dar city, Ethiopia. International Journal of Leadership in Education, 23(4), 415-427. https://doi.org/10.1080/13603124.2018.1524933

Day, C., Gu, Q., \& Sammons, P. (2016). The impact of leadership on student outcomes. Educational Administration Quarterly, 52(2), 221-258. https://doi.org/10.1177/0013161X15616863

De Hoogh, A. H. B., \& Den Hartog, D. N. (2008). Ethical and despotic leadership, relationships with leader's social responsibility, top management team effectiveness and subordinates' optimism: A multi-method study. Leadership Quarterly, 19(3), 297-311. https://doi.org/10.1016/j.leaqua.2008.03.002

Drummer, J., Hakimov, G., Joldoshov, M., Köhler, T., \& Udartseva, S. (2018). Vocational Teacher Education in Central Asia Developing Skills and Facilitating Success.

Ehrhart, M. G. (2004). Leadership and procedural justice climate as antecedents of unit-level organizational citizenship behavior. Personnel Psychology, 57(1), 61-94. https://doi.org/10.1111/j.1744-6570.2004.tb02484.x

Fayol, H., \& Storrs, C. (1949). Administration industrielle et générale. General and industrial management. Translated... by Constance Storrs, Etc. Sir Isaac Pitman \& Sons.

Francis, P. (2014). Apostolic letter to all consecrated people on the occasion of the year of consecrated life. Catholic Truth Society.

Gardner-McTaggart, A. C. (2020). Educational leadership and global crises; reimagining planetary futures through social practice. International Journal of Leadership in Education, 1-17. https://doi.org/10.1080/13603124.2020.1811900

Gay, L. R., \& Airasian, P. (1992). Education research: Competence for analysis and application. New York: Merrill.

Grant, M. J., \& Booth, A. (2009). A typology of reviews: an analysis of 14 review types and associated methodologies. Health Information \& Libraries Journal, 26(2), 91-108.

Hallinger, P., Gümüss, S., \& Bellibaş, M. Ş. (2020). "Are principals instructional leaders yet?" A science map of the knowledge base on instructional leadership, 1940-2018. Scientometrics, 122(3), 1629-1650. https://doi.org/10.1007/s11192-020-03360-5

Hallinger, P., \& Murphy, J. (1985). Assessing the instructional management behavior of principals. The Elementary School Journal, 86(2), 217-247. https://doi.org/10.1086/461445

Harris, A., \& DeFlaminis, J. (2016). Distributed leadership in practice: Evidence, misconceptions and possibilities. Management in Education, 30(4), 141-146. https://doi.org/10.1177/0892020616656734

Harris, A., \& Jones, M. (2020). COVID 19-school leadership in disruptive times. School Leadership and Management, 4O(4), 243-247. https://doi.org/10.1080/13632434.2020.1811479

Heck, R. H., \& Hallinger, P. (2009). Assessing the contribution of distributed leadership to school improvement and growth in math achievement. American Educational Research Journal, 46(3), 659-689. https://doi.org/10.3102/0002831209340042

Hermans, C. A. M. (2021). Discernment as predictor for transformational leadership: a study of school leaders in Catholic schools in India. Journal of Beliefs \& Values, 1-16. https://doi.org/10.1080/13617672.2020.1852815

Hogan, R., \& Hogan, J. (2001). Assessing Leadership: A View from the Dark Side. International Journal of Selection and Assessment, 9(1-2), 40-51. https://doi.org/10.1111/1468-2389.00162

John. (2018). Dirjen Bimas Katolik: Indonesia Membutuhkan Guru Agama Katolik • BMV Katedral Bogor. https://www.bmvkatedralbogor.org/eusebius-binsasi-indonesia-membutuhkan-guru-agama-katolik/

Kelkay, A. D. (2018). School principals' and supervisors' leadership practices in teachers' continuous professional development program: in secondary school of Bahir Dar city, Ethiopia. International Journal of Leadership in Education.

Kirchberger, G. (2014). Bahan ajar teologi, katekese dan pastoral dalam konteks gereja katolik indonesia. Jurnal Berbagi, 3(2), 184-203.

KWI. (2020). Kongregasi untuk pendidikan katolik: Mendidik untuk dialog antar buadya di sekolah-sekolah Katolik \& mendidik untuk humanis persaudaraan. Seri Dokumen Gerejawi No. 117, KWI, Jakarta.

Leithwood, K., \& Wahlstrom, K. L. (2008). Linking leadership to student learning: Introduction. Educational Administration Quarterly, 44(4), 455-457. https://doi.org/10.1177/0013161X08321495

Leonangung, E. A., Maku, H., \& Redi Partus Jaya, P. (2019). Kepemimpinan kolegial perguruan tinggi katolik Di Flores (Studi Kasus Di STKIP Santu Paulus Ruteng Dan STFK Ledalero).

Lochmiller, C. R., \& Mancinelli, J. L. (2019). Principals' instructional leadership under statewide teacher evaluation reform. International Journal of Educational Management, 33(4), 629-643. https://doi.org/10.1108/JJEM06-2017-0151

Lorensius. (2020). Aksi peduli, umat katolik keuskupan agung samarinda salurkan bantuan APD untuk tenaga 
medis-keuskupan agung Samarinda. https://kasri.or.id/2020/04/29/aksi-peduli-umat-katolikkeuskupan-agung-samarinda-salurkan-bantuan-apd-untuk-tenaga-medis/

McGregor, D., \& Cutcher-Gershenfeld, J. (1960). The human side of enterprise. McGraw-Hill New York.

Miles, M. B., \& Huberman, A. M. (1994). Qualitative data analysis: An expanded sourcebook. sage.

Netolicky, D. M. (2020). School leadership during a pandemic: navigating tensions. Journal of Professional Capital and Community, 5(3/4), 391-395. https://doi.org/10.1108/JPCC-05-2020-0017

Ningsih, K. D., Harapan, E., \& Destiniar, D. (2020). Pengaruh komite sekolah dan kepemimpinan kepala sekolah terhadap peningkatan mutu pendidikan. JMKSP (Jurnal Manajemen, Kepemimpinan, Dan Supervisi Pendidikan), 6(1), 1-14. https://doi.org/10.31851/jmksp.v6i1.3921

Northouse, P. G. (2015). Leadership: Theory and practice. SAGE Publications, Incorporated.

O’Hara, J., Shevlin, P., Brown, M., \& McNamara, G. (2021). Educational networks: a key driving force for school development in a time of crisis and change. SHS Web of Conferences, 98, 02003. https://doi.org/10.1051/shsconf/20219802003

Pietsch, M., Tulowitzki, P., \& Hartig, J. (2019). Examining the effect of principal turnover on teaching quality: a study on organizational change with repeated classroom observations. School Effectiveness and School Improvement, 1-23. https://doi.org/10.1080/09243453.2019.1672759

Pope Paul VI. (1965). Gravissimum educationis. https://www.vatican.va/archive/hist_councils/ii_vatican_ council/documents/vat-ii_decl_19651028_gravissimum-educationis_en.html

Popper, M., \& Lipshitz, R. (1998). Organizational Learning Mechanisms: A Structural and Cultural Approach to Organizational Learning. Journal of Applied Behavioral Science, 34(3), 161-179. https://doi.org/10.1177/0021886398342003

Purwanto, A., Wijayanti, L. M., Hyun, C. C., \& Asbari, M. (2019). the effect of tansformational, transactional, authentic and authoritarian leadership style toward lecture performance of private University in Tangerang. Dinasti International Journal of Digital Business Management, 1(1), $29-42$. https://doi.org/10.31933/dijdbm.v1i1.88

Ribbins, P. (2007). Leadership and management in education: what's in a field? South African Journal of Education, 27(3), 351-376.

Sandiasa, G. (2017). Kepemimpinan transformasional dan strategi pengembangan institusi dalam meningkatkan kualitas perguruan tinggi. Prosiding Seminar : Revitalisasi Tata Kelola Perguruan Tinggi Juni, 13-26.

Sarumaha, A. (2018). Penguatan Lembaga Pendidikan Tinggi Keagamaan: Penelitian Dosen PTAK. SAPA-Jurnal Kateketik Dan Pastoral, 3(1), 18-42.

Sebastian, J., Allensworth, E., Wiedermann, W., Hochbein, C., \& Cunningham, M. (2019). Principal Leadership and School Performance: An Examination of Instructional Leadership and Organizational Management. Leadership and Policy in Schools, 18(4), 591-613. https://doi.org/10.1080/15700763.2018.1513151

Spillane, J. P. (2004). Distributed leadership: What's all the hoopla? institute for policy research, northwestern university, 1-10. http://hub.mspnet.org

Stone-Johnson, C., \& Miles Weiner, J. (2020). Principal professionalism in the time of COVID-19. Journal of Professional Capital and Community, 5(3-4), 367-374. https://doi.org/10.1108/JPCC-05-2020-0020

Taylor, F. W. (1947). The principles of scientific management", in Scientific Management, Harper \& Row, New York, NY.

Tolo, A., Lillejord, S., Flórez Petour, M. T., \& Hopfenbeck, T. N. (2020). Intelligent accountability in schools: A study of how school leaders work with the implementation of assessment for learning. Journal of Educational Change, 21(1), 59-82. https://doi.org/10.1007/s10833-019-09359-x

United States Conference of Catholic Bishops. (2015). USCCB response to Educating Today and Tomorrow in Educating today and tomorrow: A renewing passion. World congress on Catholic education. https://www.usccb.org/beliefs-and-teachings/how-we-teach/catholic-education/k-12/upload/15-076Final-World-Congress.pdf

Wee, B. Van, \& Banister, D. (2016). How to write a literature review paper? transport reviews, 36(2), $278-288$. https://doi.org/10.1080/01441647.2015.1065456

Zhang, Q., Siribanpitak, P., \& Charoenkul, N. (2018). Creative leadership strategies for primary school principals to promote teachers' creativity in Guangxi, China. Kasetsart Journal of Social Sciences. https://doi.org/10.1016/j.kjss.2018.08.007

Zhao, Y. (2020). COVID-19 as a catalyst for educational change. Prospects, 49(1-2), 29-33. https://doi.org/10.1007/s11125-020-09477-y 